\title{
An Insight in Electrocoagulation Process through Current Density Distribution (CDD)
}

\author{
Djamel Ghernaout ${ }^{1,2 *}$, Noureddine Elboughdiri ${ }^{1,3}$ \\ ${ }^{1}$ Chemical Engineering Department, College of Engineering, University of Ha'il, Ha'il, KSA \\ ${ }^{2}$ Chemical Engineering Department, Faculty of Engineering, University of Blida, Blida, Algeria \\ ${ }^{3}$ Département de Génie Chimique de Procédés, Laboratoire Modélisation, Analyse, et Commande des systèmes, Ecole Nationale \\ d’Ingénieurs de Gabès (ENIG), Gabès, Tunisia \\ Email: ${ }^{\star d j a m e l \_a n d a l u s @ h o t m a i l . c o m ~}$
}

How to cite this paper: Ghernaout, D. and Elboughdiri, N. (2020) An Insight in Electrocoagulation Process through Current Density Distribution (CDD). Open Access Library Journal, 7: e6142.

https://doi.org/10.4236/oalib.1106142

Received: February 5, 2020

Accepted: February 21, 2020

Published: February 24, 2020

Copyright $\odot 2020$ by author(s) and Open Access Library Inc.

This work is licensed under the Creative Commons Attribution International License (CC BY 4.0).

http://creativecommons.org/licenses/by/4.0/

\begin{abstract}
Electrocoagulation (EC) is a flourishing technique in the field of water treatment implementations. Numerous investigations have been performed to assess the performance of EC to eliminate different pollutants; however, the more basic electrochemical features of the technique are usually ignored. Scientists such as McBeath et al. [1] provided an understanding of the essential link of water flow, electrochemical metal dissolution, and current density distribution (CDD) via computational fluid dynamic (CFD) models, mathematical models, and in situ CDD determination tests. They established, in theory, that current distributed over the electrode was inversely proportional to the water flow rate. By means of the CFD models and current distribution determining technique, they noted that current density was distributed unequally and pursued the tendency anticipated via theory. Eliminating natural organic matter was decreased as much as $79 \%$ when the inter-electrode distance was diminished from 10 to $1 \mathrm{~mm}$. As a perspective, more efforts are required to better understand the $\mathrm{CDD}$ at the anodes surface and electric charges transfer from electrodes to the bulk of the solution. Mechanisms related to interactions of anodic metallic cations and various pollutants should be more investigated.
\end{abstract}

\section{Subject Areas}

Environmental Sciences

\section{Keywords}

Electrocoagulation, Computational Fluid Dynamic (CFD), Current Density Distribution (CDD), Natural Organic Matter (NOM), Fluoride, Arsenic 


\section{Introduction}

Numerous electrochemical techniques have acquired great interest for next combination into water treatment technologies [1] [2] [3] [4] [5]. Electrocoagulation (EC) has been found encouraging as a substitutional method to classical chemical coagulation for some potable water, municipal and industrial wastewater implementations [6] [7] [8]. EC avoids the chemical supply chain needed for traditional coagulation [9] [10] [11] [12], since coagulant chemicals are electrochemically formed in situ and on-demand [13]. Through applying current with an external power supply to an electrochemical setup, the two half-cell reactions of anodic metal dissolution and cathodic reduction of water make possible the global formation of metal hydroxide and metal oxide species: i.e., the coagulant chemicals [14]. As current furnished to the cell augments, the rate of anodic metal dissolution and water reduction at the cathode surface augments, therefore leading to the elevated generation of coagulant [15] [16]. Until now, much of the EC study has focused on the process's capability to eliminate diverse pollutants, comprising both organic and inorganic products and microorganisms [17]-[23], while investigating the effect of various process variables such as metal loading (coagulant dose) [24], charge loading [25] [26], pH [27] [28] [29] [30], anode metal material (usually aluminum or iron) [31]-[39], reactor design [40], supporting electrolyte [41], initial contaminant concentrations [42] and scale-up [43] [44] [45] [46] [47].

Another factor that has been largely tested is the impact of the current density on the EC performance [48] [49]. Several scientists have followed the influence of current density on the reduction of different pollutants throughout the EC application (Figure 1). As an example, the impact of current density on the reduction of organic dyes present in textile wastewaters was observed to be very little; however, a proportional elevation of dye elimination and current density augmentation was yielded [50]. Additional scientists noted a huge augmentation in dye reduction with elevating current density [51]. The augmented removal of sulfide and chemical oxygen demand from spent caustic wastewater was as well shown with elevating current density [52]. In both investigations, current density was commanded via varying the applied current, as opposed to modifying the electrode surface area at constant current operation. Due to this, the consequences of augmented coagulant production and dosing on bigger pollutant elimination at more important current densities stay obscure [1].

The influence of current density on the EC technology has as well been largely studied for drinking water treatment applications [24] [26] [31]. Scientists [53] [54] [55] discovered that current density had few impact on the reduction of fluoride from groundwater. They imputed the augmented removal of fluoride at more important current densities to the elevated coagulant production at the higher metal loading related to greater current density. Current density was as well established to hugely touch the efficiency of EC to eliminate arsenic from groundwater; however, in this situation arsenic reduction capability diminished 


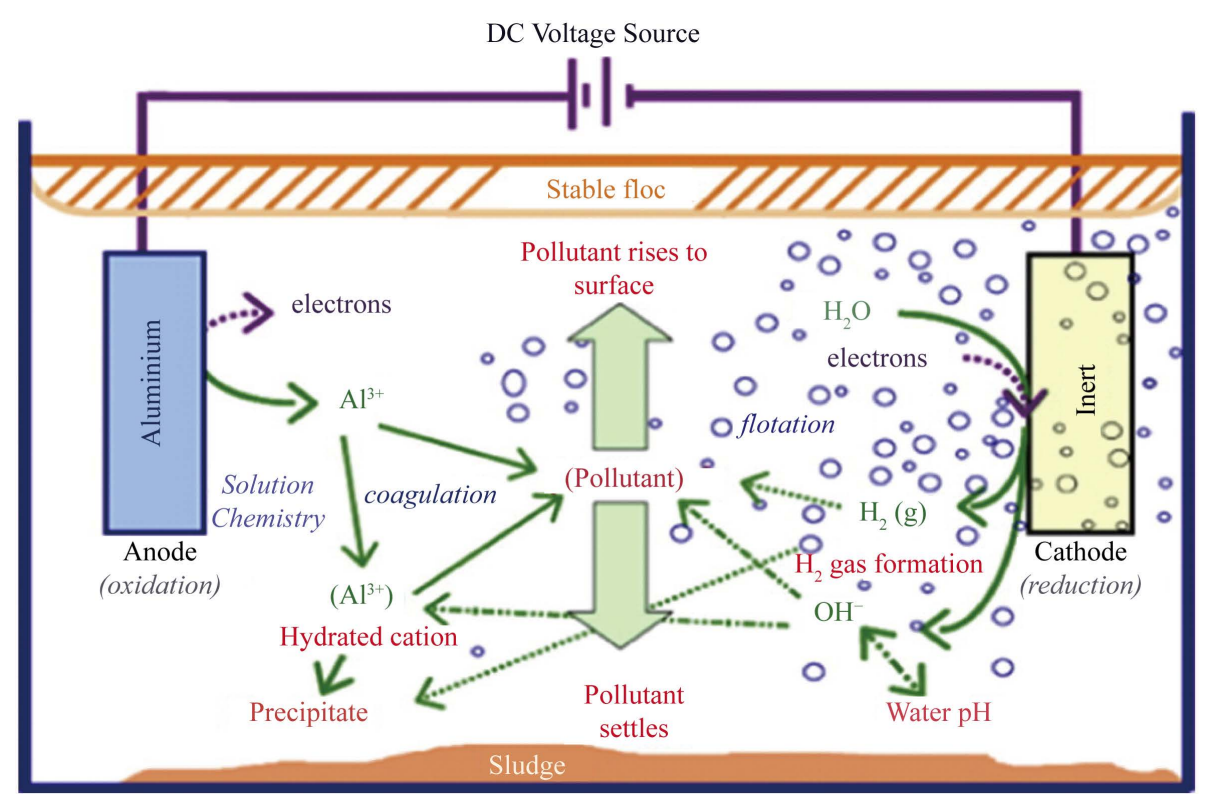

Figure 1. Interactions taking place inside EC reactor [48] (although on this figure, there is an inert cathode, in discussion, the cathode has been often considered made of the same material as the anode to explain chemical dissolution [49]).

with augmenting current density [1]. Additional investigation has noted the adverse influence for arsenic reduction, but this was over more possibly because of the augmented metal loading that joined the augmentation in applied current [56]. Several batch-scale trials have illustrated that the reduction of natural organic matter (NOM) from synthetic and raw surface water as well augmented when current density was decreased [57]. When an identical method was scaled-up to a continuous flow mode, the impact was reduced and no obvious tendency was shown among current density and the elimination capability of NOM [1]. Current density has also been established to possess an influence on local pH near the electrode, as well as dissolved oxygen level, then touching the speciation of iron hydroxide coagulants which are produced throughout the EC method [58].

Even if the influence of current density has been broadly studied, in company with additional technique factors, there are no great attempts dedicated to comprehending the basic electrochemical and transport phenomena fundamentally regulating the distribution of current on the electrode surface. Especially, there has been a shortage of studies to sense the link among the variable movement of water across an EC electrode surface and its dependent impact on the current density distribution (CDD). In almost all previous EC investigations, it was supposed that current density stays constant over the entire electrode surface throughout the galvanostatic operation. Such as other electrochemical techniques, below most conditions, this is possibly not achieved because of several parameters comprising electrolyte (water) velocity fluctuations across the electrode surface. The decomposition of the sacrificial anode may take place because of three principal causes: electrochemical oxidation (debated here), chemical 
dissolution, and mechanical erosion. In the existence of an oxidation current, the proportions of the two other phenomena are minor if contrasted to electrochemical oxidation. As a result, the distribution of the anode decomposition is related to the inhomogeneity in the electric current distribution [1].

In many former investigations, current density has been modeled for an EC technique and was determined to be a fundamental parameter for assessing the electrode order and geometry for energy consumptions, since it was not uniformly expanded [59]. It has as well been before illustrated via modeling, that this irregular expansion of current and potential over an EC electrode may touch coagulant production, in the end influencing the EC efficacy [60]. Computational fluid dynamic (CFD) modeling has as well been employed for the divination of electrolyte flow changes inside an EC device, showing elevated changes of fluid velocity inside the setups, as a consequence of numerous parameters involving cell geometry and arrangement [49] [61]. Broadly, CFD modeling is a largely utilized tool in electrochemical engineering to comprehend electrolyte mass transport phenomena. Phenomenological studies of the EC method have explained the mixing [62] and technique [63] regulation procedures. Fresh numerical investigations on EC have been dedicated to the contribution of the setup arrangement in the electric field and mass transport [1]; however, the action of local reaction circumstances on the identical electrode plate has not been examined [64].

\section{In Situ Evaluation of Current Density Distribution (CDD) and Fluid Modeling of an EC Method}

With a view to comprehend the fluctuation of the current distribution over an electrode surface, McBeath et al. [1] utilized an in situ manner to meter and chart the CDD. Further, water flow patterns into and out of the EC device got via CFD modeling, with a view to give penetration towards the fluid and current flow bond (Figure 2). Besides giving an essential comprehension of current and mass transport importance for enhanced and foreseeable EC applications, as well as furnishing a new method implementation for distinguishing current distribution in an EC setup, findings may conduct to the ameliorated CDD and so enhanced reactor design; a basic parameter for the design of an energy-efficient and thus more economical EC reactor and process [1].

McBeath et al. [1] focused on the key link of water flow, electrochemical metal dissolution, and CDD via CFD models, mathematical models, and in situ CDD identification tests. In theory, it was established that current distributed across the electrode was inversely proportional to the water flow rate. The turbulent flow into and out of the EC setup was simulated with changing inter-electrode distances and flow rates; however, the average velocity segments over the electrode surface was evaluated, corresponding to the identical segments utilized to experimentally assess the current distribution. By means of the CFD models and current distribution assessing manner, McBeath et al. [1] noted that current 


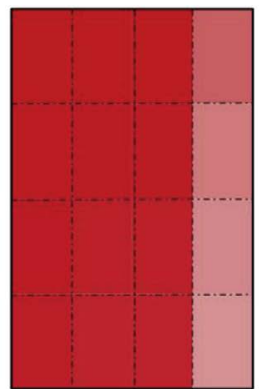

$1 \mathrm{~mm}$
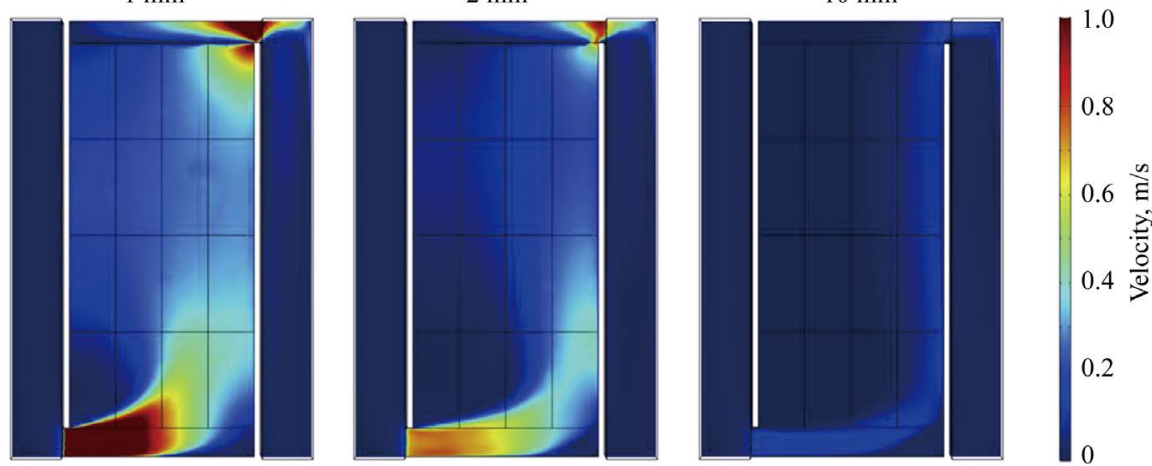

Figure 2. Current density (partial electrode approach) and water velocity profiles (CFD models) for $1.35 \mathrm{~L} / \mathrm{min}$ flow at 1,2 and $10 \mathrm{~mm}$ gaps [1].

density was distributed unequally and pursued the tendency prevised by theory. Regions of lower current density were frequently joined by the higher-velocity flow. The more regular current was yielded with larger inter-electrode distances, because of the greater flow regularity. However, working with a $1 \mathrm{~mm}$ distance, the current and water velocity changed over the electrode by $\Delta 27.6 \mathrm{~mA} / \mathrm{cm}^{2}$ and $\Delta 0.220 \mathrm{~m} / \mathrm{s}$, and was decreased to $\Delta 3.6 \mathrm{~mA} / \mathrm{cm}^{2}$ and $\Delta 0.062 \mathrm{~m} / \mathrm{s}$ at a $10 \mathrm{~mm}$ distance. Even if current regularity was augmented, the global current density diminished greatly because of the bigger ohmic resistance related to the greater distance. The elimination of NOM was decreased as much as $79 \%$ when the inter-electrode separation was decreased from 10 to $1 \mathrm{~mm}$.

\section{Reviewing EC Modeling Procedures}

Hakizimana et al. [49] published a thorough discussion of EC development and design. They focused on the theoretical comprehension of pathways controlling contamination removal, modeling manners, CFD simulations (Figure 3), and techno-economic optimization.

Further, Hakizimana et al. [49] discussed the most important parameters that affect EC process efficiency (Figure 4).

\section{Discussing EC for Arsenic Removal}

Song et al. [65] presented the fresh development of arsenic elimination via EC method involving the impacts of main working factors, optimization of the EC efficiency, as well as the estimation of EC device arrangements. They contrasted 


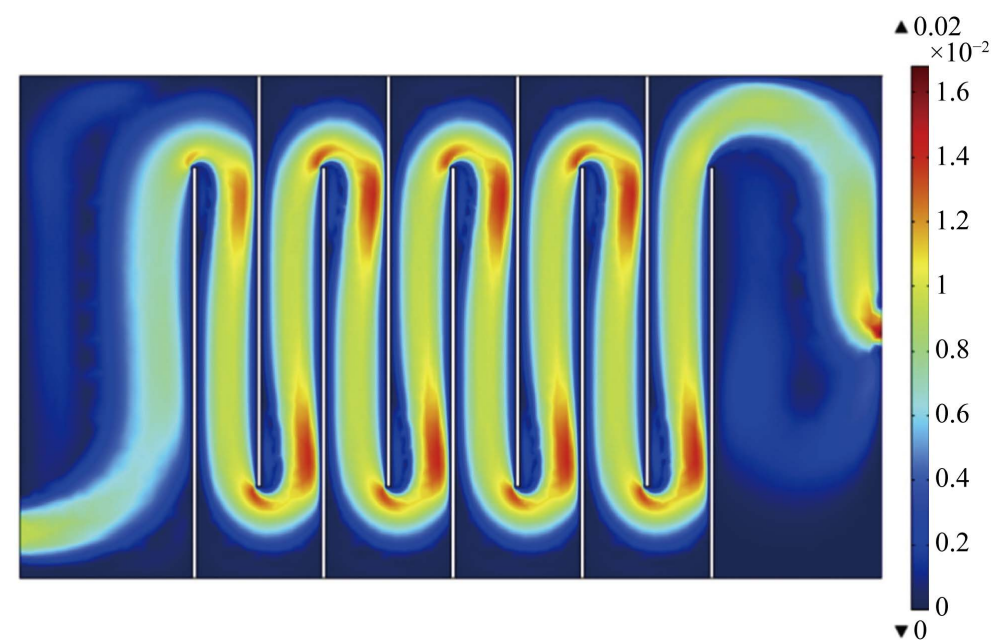

(a)

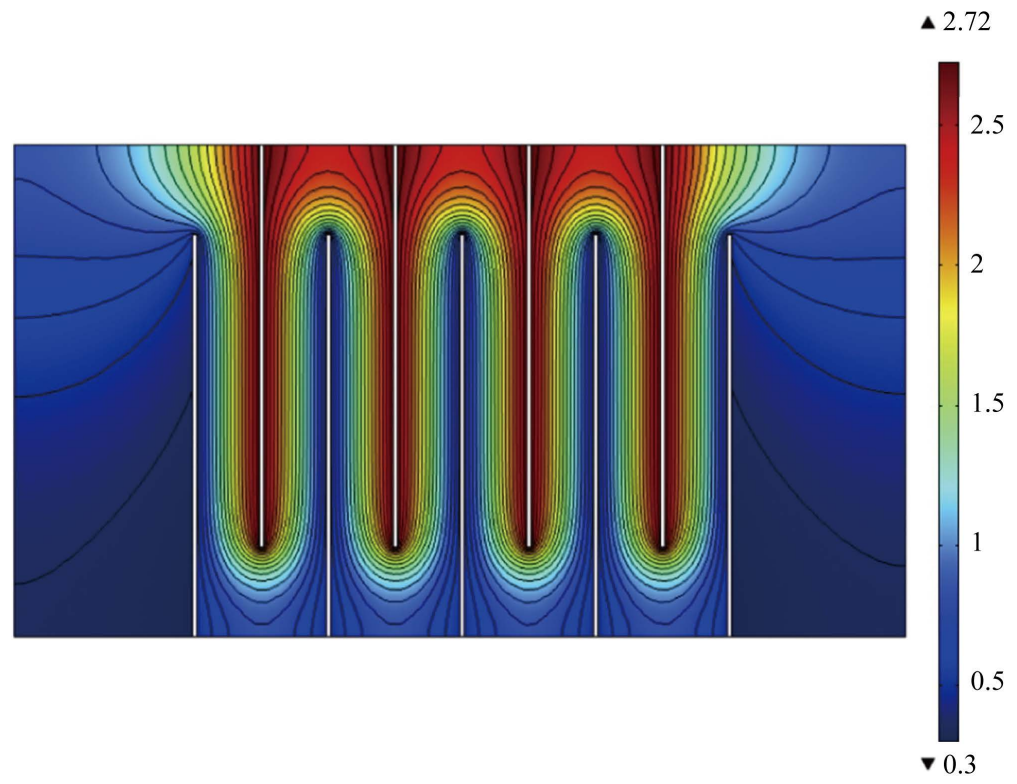

(b)

Figure 3. (a) Flow pattern (b) velocity magnitude and secondary potential distributions throughout an EC cell at a flow rate $0.5 \mathrm{~L} / \mathrm{min}$ [49].

the efficiency of EC and other techniques and focused on future research needs for arsenic removal in the EC process. They concluded that EC appears as an environmentally friendly and performant technology for arsenic elimination. Nevertheless, it is affected by many restrictions like high energy consumption in large scales and difficulty of EC reactor design. More researches are needed to get the better of the disadvantages to expand the handy usage and pointedly examine the EC efficiency of arsenic elimination.

\section{CFD Simulation of Biphasic Flow in EC Device}

The mass transport efficiency of $\mathrm{Al}^{3+}$ ion is in charge of the formation of the coagulant within the EC device, and, therefore, removing pollutants is a function 


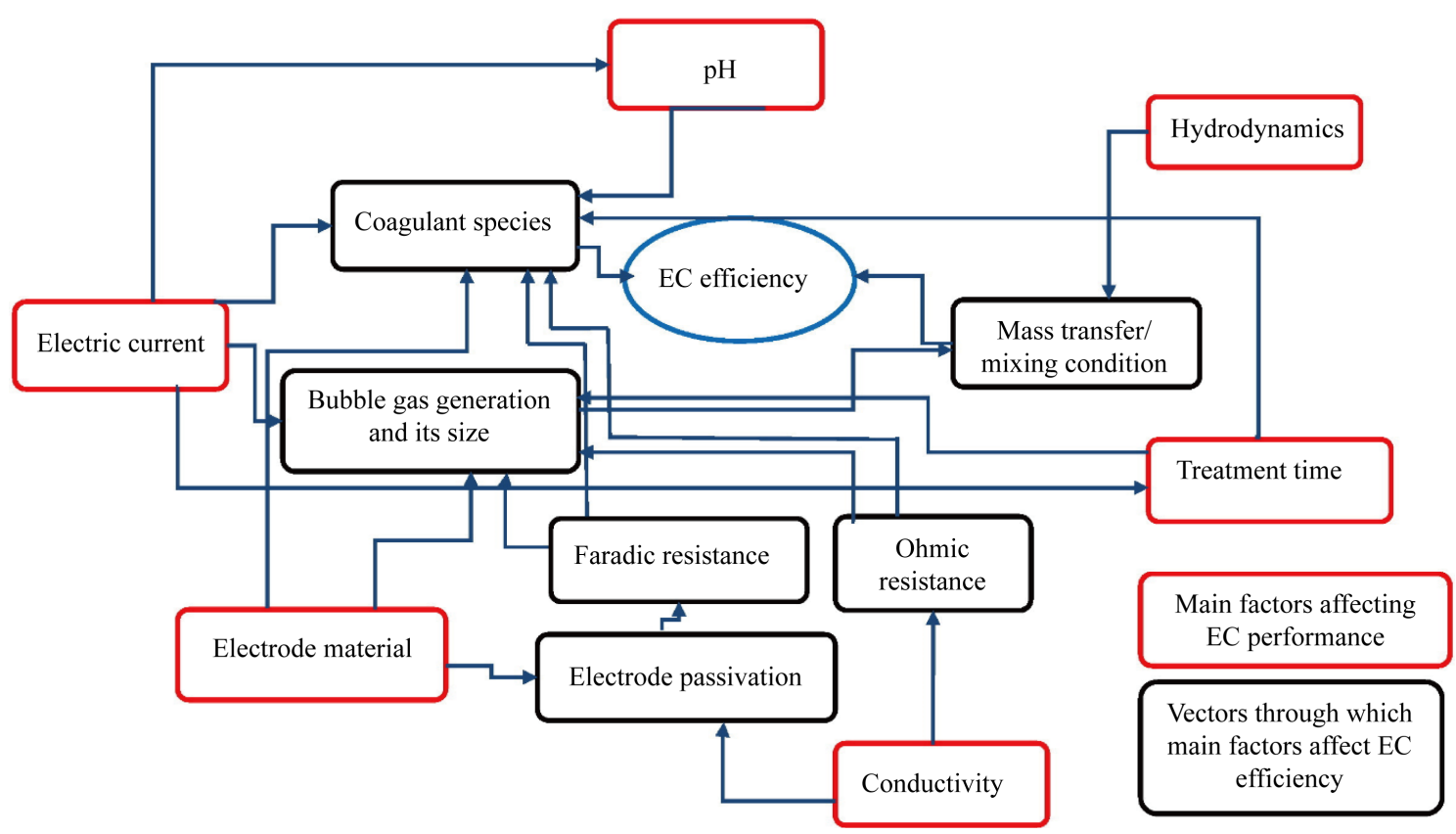

Figure 4. Principal parameters touching EC technology [49].

of it. In identical fashion, the hydrogen gas emanation in the counter-electrode touches the setup efficiency because of the resistivity produced in the solution and the biphasic fluid dynamics (Figure 5). The suggested model explains at once the secondary current distribution, the mass transport of aluminum and hydrogen, and the momentum transfer of a turbulent biphasic system in a continuous rotating cylinder electrode (RCE) reactor combined with two sedimentation tanks [66]. The theoretical analysis for this system showed well-mixed circumstances and a quasi-uniform current distribution in the RCE reactor thanks to the geometrical design and the low quantities of hydrogen gas formed at the different current values investigated (Figure 6). For the present, slow flow velocities and dead zones were noted within the sedimentation tanks. Plus, comparisons among experimental, and theoretical $\mathrm{Al}^{3+}$ concentrations under stationary regime are also presented, found a good correlation [66].

\section{Eliminating Fluoride and Hydrated Silica by EC in a Flow Channel Reactor}

Castañeda et al. [67] focused on the concomitant elimination of fluoride and hydrated silica from groundwater $(4.08 \mathrm{mg} / \mathrm{L}$ fluoride, $90 \mathrm{mg} / \mathrm{L}$ hydrated silica, $50 \mathrm{mg} / \mathrm{L}$ sulfate, $0.23 \mathrm{mg} / \mathrm{L}$ phosphate, $\mathrm{pH} 7.38$ and $450 \mu \mathrm{S} / \mathrm{cm}$ conductivity) via EC, employing an up-flow EC setup, with a six-cell stack in a serpentine array, opened at the top of the cell to favor gas liberation (Figure 7). Aluminum plates were employed as sacrificial electrodes. They assessed the impact of current density $\left(4 \leq j \leq 7 \mathrm{~mA} / \mathrm{cm}^{2}\right)$ and mean linear flow rate $(1.2 \leq u \leq 4.8 \mathrm{~cm} / \mathrm{s})$, implemented to the EC reactor, on the elimination of fluoride and hydrated silica. The elimination of fluoride satisfied the WHO guideline $(<1.5 \mathrm{mg} / \mathrm{L})$; however, the 


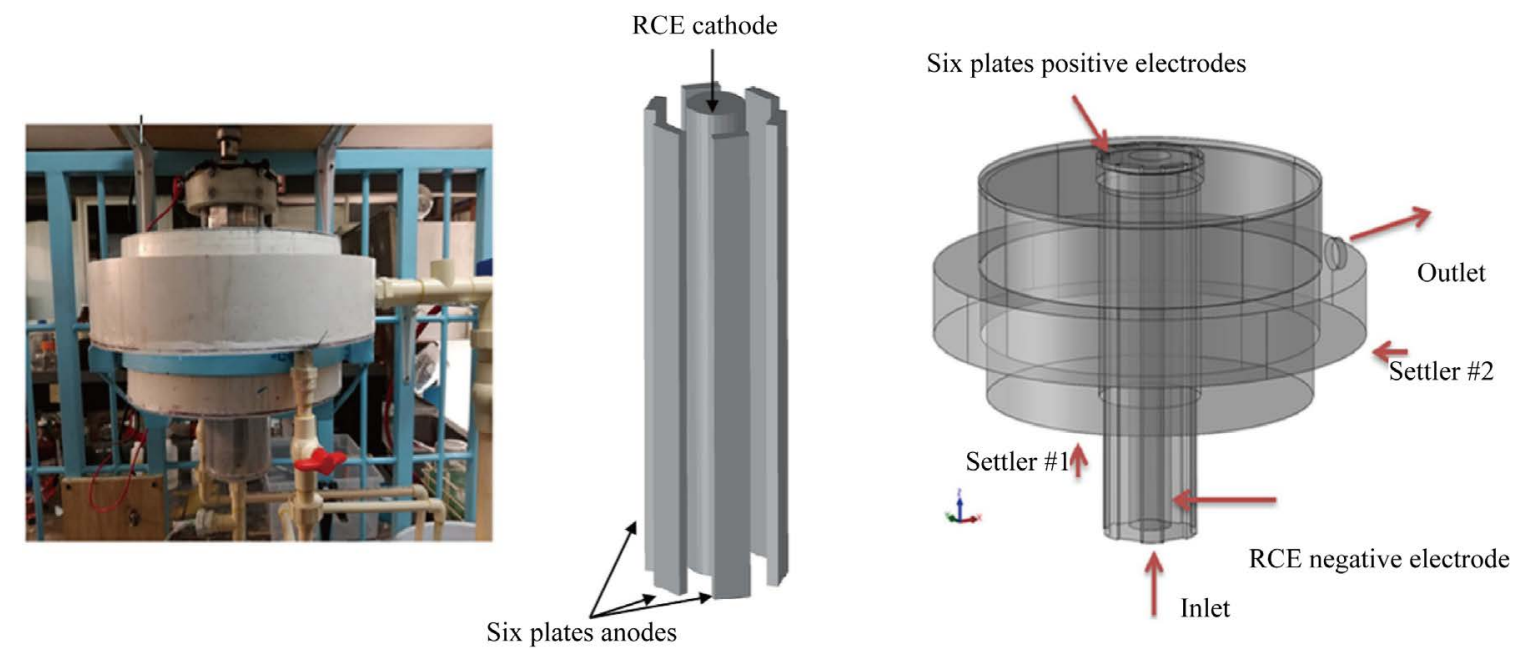

Figure 5. (a) EC lab configuration system, (b) electrodes arrangement inside the reactor and (c) 3D computational domain of the system [66].

(a)

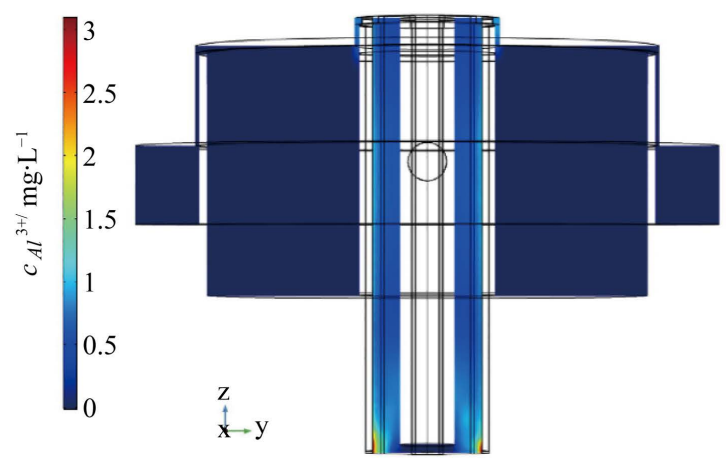

(c)

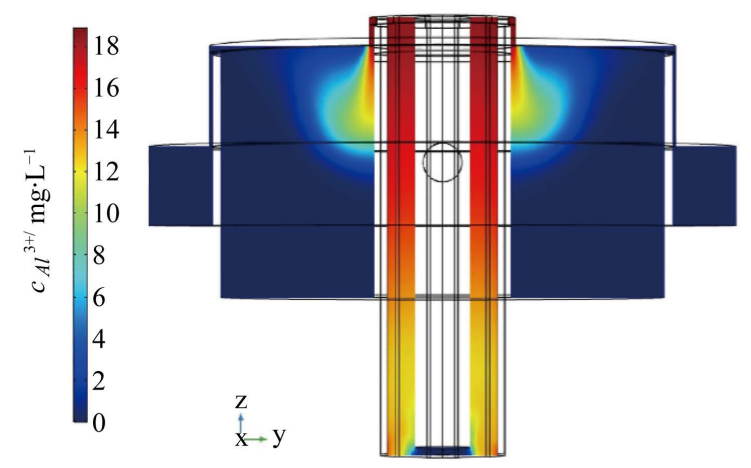

(b)

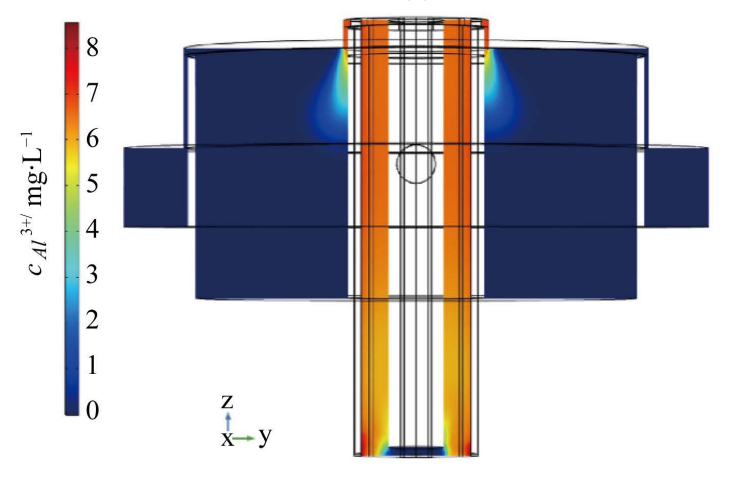

(d)

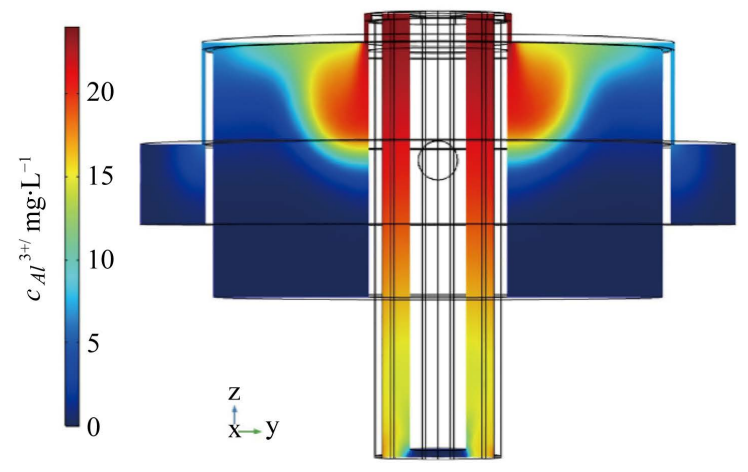

Figure 6. Aluminum ion concentrations in the middle of the domain at $z$ - $y$ plane at different times of (a) $5 \mathrm{~s}$, (b) 50 $\mathrm{s}$, (c) $200 \mathrm{~s}$ and (d) $500 \mathrm{~s}$ for $j_{\text {ave }}=32 \mathrm{~A} / \mathrm{m}^{2}$ at $100 \mathrm{rpm}$ with an input flow of $0.4 \mathrm{~L} / \mathrm{min}$ [66].

hydrated silica was reduced at $7 \mathrm{~mA} / \mathrm{cm}^{-2}$ and $1.2 \mathrm{~cm} / \mathrm{s}$, with energy consumption of $2.48 \mathrm{kWh} / \mathrm{m}^{3}$ and an overall operational cost of $0.441 \mathrm{USD} / \mathrm{m}^{3}$. Spectroscopic analyses of the flocs by XRD, XRF-EDS, SEM-EDS, and FTIR proved that hydrated silica reacted with the coagulant forming aluminosilicates, and fluoride replaced a hydroxide from aluminum aggregates, while sulfates and phosphates 
(a)

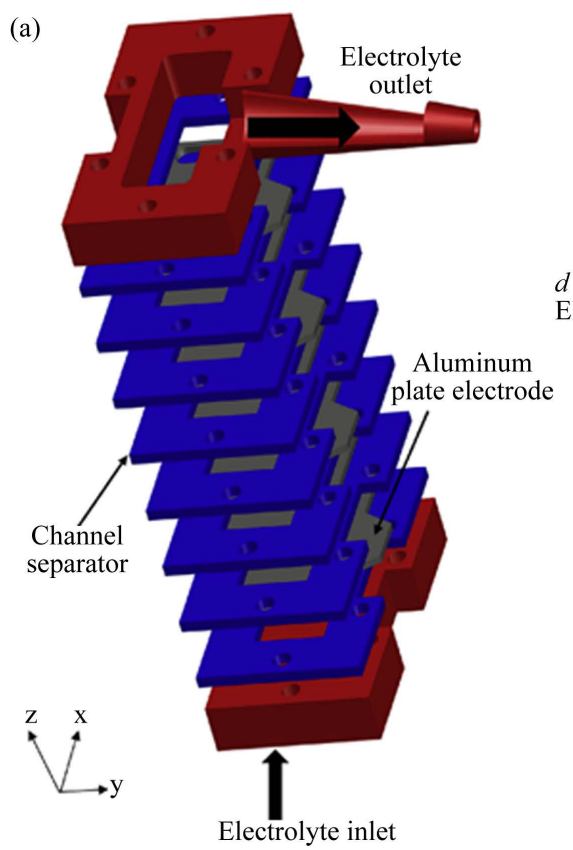

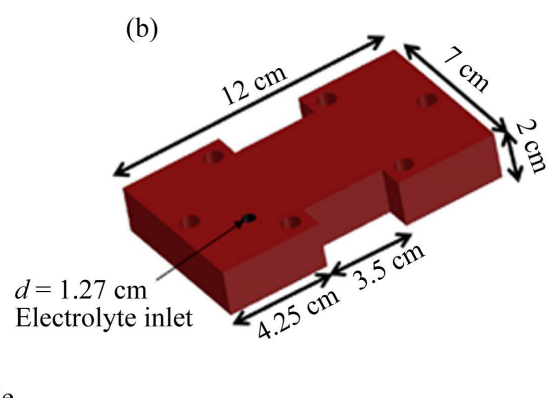

(d)
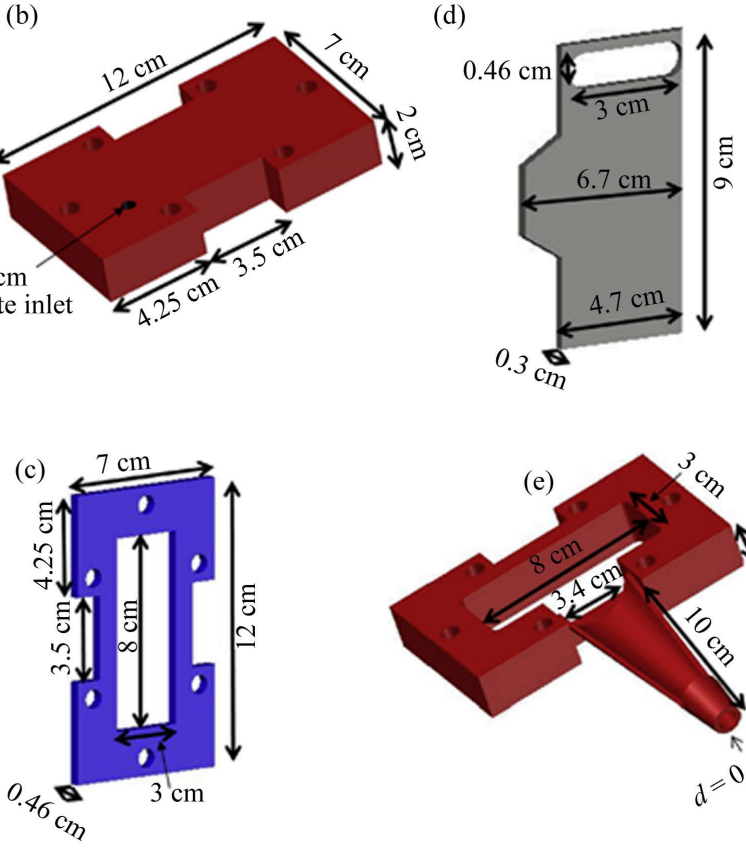

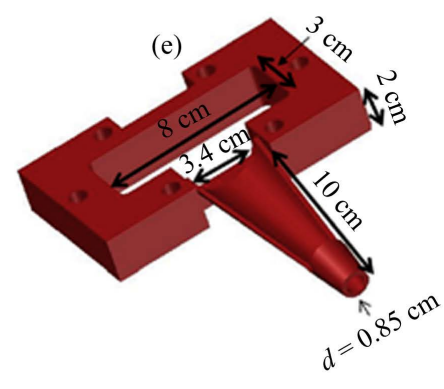

Figure 7. (a) Sketch of the reactor, (b) bottom plate, (c) channel separator, (d) aluminum electrode, and (e) electrolyte collector at the exit [67].

were removed by adsorption process onto the flocs. The well-engineered EC device allowed the simultaneous elimination of fluoride and hydrated silica.

\section{Conclusions}

From this work, the following conclusions can be drawn:

1) An in situ manner for the determination of CDD for an EC method was used in parallel with mathematical and CFD modeling for iron dissolution and water velocity variation analysis, respectively [1]. The current density information coincided well with the models; however, regions of elevated current density were inversely matched to regions of low-velocity fluid flow and thus, augmented $\mathrm{Fe}^{2+}$ dissolution. As the inter-electrode separation augmented, water velocity fluctuations greatly diminished, conducting to importantly elevated current density regularity. From the current distribution information, a more precise view of iron dissolution efficiency is reached, whereby local $\mathrm{Fe}^{2+}$ dissolution rates could be evaluated. Throughout $1 \mathrm{~mm}$ inter-electrode distance trials, current and water velocity fluctuations were $\Delta 27.6 \mathrm{~mA} / \mathrm{cm}^{2}$ and $\Delta 0.220 \mathrm{~m} / \mathrm{s}$, respectively. If the inter-electrode distance augmented to $10 \mathrm{~mm}$, this variance diminished to $\Delta 3.6 \mathrm{~mA} / \mathrm{cm}^{2}$ and $\Delta 0.062 \mathrm{~m} / \mathrm{s}$. This augmented current uniformity did have effects on the global achievable current density; nevertheless, because of the importantly elevated ohmic resistance related to the broader distance. In addition to reduced current density, the related elevation in electrical potential hugely elevates running energy needs. Moreover, NOM elimination suffered at bigger inter-electrode separations, whereby dissolved organic carbon removal was observed to increase from 16, 29 and 46\%, during 10,2 and $1 \mathrm{~mm}$ opera- 
tions.

2) Regardless of EC being a robust and versatile technology, it stays harder to simulate than other water treatment techniques, like biological methods. Two main investigation fields appear fundamental for a more successful exploration of the EC process. The first one implicates the implementation of CFD to EC method that needs to be expanded and should involve mixing phenomena, and the second one focuses on the separation stage of EC, via flotation or settling, in the existence of an electric that both require experimental and theoretical analysis [49].

3) Recently, there is huge progress in terms of investigating the EC process especially in the influence of CDD. Nevertheless, more efforts are required to better understand the CDD at the electrodes surface and electric charges transfer from electrodes to the bulk of the solution. Mechanisms related to interactions of anodic metallic cations and various pollutants should be more investigated.

\section{Conflicts of Interest}

The authors declare no conflicts of interest regarding the publication of this paper.

\section{References}

[1] McBeath, S.T., Nouri-Khorasani, A., Mohseni, M. and Wilkinson, D.P. (2020) In-Situ Determination of Current Density Distribution and Fluid Modeling of an Electrocoagulation Process and Its Effects on Naturalorganic Matter Removal for Drinking Water Treatment. Water Research, 171, Article ID: 115404. https://doi.org/10.1016/j.watres.2019.115404

[2] Radjenovic, J. and Sedlak, D.L. (2015) Challenges and Opportunities for Electrochemical Processes as Next-Generation Technologies for the Treatment of Contaminated Water. Environmental Science \& Technology, 49, 11292-11302. https://doi.org/10.1021/acs.est.5b02414

[3] Ghernaout, D., Ghernaout, B. and Naceur, M.W. (2011) Embodying the Chemical Water Treatment in the Green Chemistry: A Review. Desalination, 271, 1-10. https://doi.org/10.1016/j.desal.2011.01.032

[4] Ghernaout, D. (2017) Environmental Principles in the Holy Koran and the Sayings of the Prophet Muhammad. American Journal of Environmental Protection, 6, 75-79. https://doi.org/10.11648/j.ajep.20170603.13

[5] Ghernaout, D., Elboughdiri, N. and Ghareba, S. (2020) Fenton Technology for Wastewater Treatment: Dares and Trends. Open Access Library Journal, 7, e6045. https://doi.org/10.4236/oalib.1106045

[6] Ghernaout, D., Naceur, M.W. and Ghernaout, B. (2011) A Review of Electrocoagulation as a Promising Coagulation Process for Improved Organic and Inorganic Matters Removal by Electrophoresis and Electroflotation. Desalination and Water Treatment, 28, 287-320. https://doi.org/10.5004/dwt.2011.1493

[7] Ghernaout, D. (2018) Electrocoagulation Process: Achievements and Green Perspectives. Colloid and Surface Science, 3, 1-5. https://doi.org/10.11648/j.css.20180301.11

[8] Ghernaout, D. and Elboughdiri, N. (2020) Electrochemical Technology for Waste- 
water Treatment: Dares and Trends. Open Access Library Journal, 7, e6020. https://doi.org/10.4236/oalib.1106020

[9] Ghernaout, B., Ghernaout, D. and Saiba, A. (2010) Algae and Cyanotoxins Removal by Coagulation/Flocculation: A Review. Desalination and Water Treatment, 20, 133-143. https://doi.org/10.5004/dwt.2010.1202

[10] Ghernaout, D. and Ghernaout, B. (2012) Sweep Flocculation as a Second Form of Charge Neutralization: A Review. Desalination and Water Treatment, 44, 15-28. https://doi.org/10.1080/19443994.2012.691699

[11] Ghernaout, D. and Ghernaout, B. (2012) On the Concept of the Future Drinking Water Treatment Plant: Algae Harvesting from the Algal Biomass for Biodiesel Production: A Review. Desalination and Water Treatment, 49, 1-18. https://doi.org/10.1080/19443994.2012.708191

[12] Ghernaout, D. (2014) The Hydrophilic/Hydrophobic Ratio vs. Dissolved Organics Removal by Coagulation: A Review. Journal of King Saud University-Science, 26, 169-180. https://doi.org/10.1016/j.jksus.2013.09.005

[13] Ghernaout, D., Al-Ghonamy, A.I., Naceur, M.W., Ait Messaoudene, N. and Aichouni, M. (2014) Influence of Operating Parameters on Electrocoagulation of C.I. Disperse Yellow 3. Journal of Electrochemical Science and Engineering, 4, 271-283. https://doi.org/10.5599/jese.2014.0065

[14] Ghernaout, D., Al-Ghonamy, A.I., Irki, S., Grini, A., Naceur, M.W., Ait Messaoudene, N. and Aichouni, M. (2014) Decolourization of Bromophenol Blue by Electrocoagulation Process. Trends in Chemical Engineering, 15, 29-39.

[15] Ghernaout, D., Benblidia, C. and Khemici, F. (2015) Microalgae Removal from Ghrib Dam (Ain Defla, Algeria) Water by Electroflotation Using Stainless Steel Electrodes. Desalination and Water Treatment, 54, 3328-3337. https://doi.org/10.1080/19443994.2014.907749

[16] Ghernaout, D., Al-Ghonamy, A.I., Ait Messaoudene, N., Aichouni, M., Naceur, M.W., Benchelighem, F.Z. and Boucherit, A. (2015) Electrocoagulation of Direct Brown 2 (DB) and BF Cibacete Blue (CB) Using Aluminum Electrodes. Separation Science and Technology, 50, 1413-1420.

https://doi.org/10.1080/01496395.2014.982763

[17] Ghernaout, D. (2017) Microorganisms' Electrochemical Disinfection Phenomena. EC Microbiology, 9, 160-169.

[18] Ghernaout, D., Aichouni, M. and Touahmia, M. (2019) Mechanistic Insight into Disinfection by Electrocoagulation: A Review. Desalination and Water Treatment, 141, 68-81. https://doi.org/10.5004/dwt.2019.23457

[19] Ghernaout, D., Alghamdi, A. and Ghernaout, B. (2019) Microorganisms' Killing: Chemical Disinfection vs. Electrodisinfection. Applied Engineering, 3, 13-19.

[20] Ghernaout, D. (2019) Greening Electrocoagulation Process for Disinfecting Water. Applied Engineering, 3, 27-31.

[21] Ghernaout, D. (2019) Electrocoagulation Process for Microalgal Biotechnology: A Review. Applied Engineering, 3, 85-94.

[22] Ghernaout, D. (2019) Virus Removal by Electrocoagulation and Electrooxidation: New Findings and Future Trends. Journal of Environmental Science and Allied Research, 2019, 85-90. https://doi.org/10.29199/2637-7063/ESAR-202024

[23] Ghernaout, D. (2019) Electrocoagulation and Electrooxidation for Disinfecting Water: New Breakthroughs and Implied Mechanisms. Applied Engineering, 3, 125-133. 
[24] Ghernaout, D., Badis, A., Ghernaout, B. and Kellil, A. (2008) Application of Electrocoagulation in Escherichia coli Culture and Two Surface Waters. Desalination, 219, 118-125. https://doi.org/10.1016/j.desal.2007.05.010

[25] Ghernaout, D., Ghernaout, B. and Kellil, A. (2009) Natural Organic Matter Removal and Enhanced Coagulation as a Link between Coagulation and Electrocoagulation. Desalination and Water Treatment, 2, 203-222.

https://doi.org/10.5004/dwt.2009.116

[26] Ghernaout, D., Ghernaout, B., Boucherit, A., Naceur, M.W., Khelifa, A. and Kellil, A. (2009) Study on Mechanism of Electrocoagulation with Iron Electrodes in Idealised Conditions and Electrocoagulation of Humic Acids Solution in Batch Using Aluminium Electrodes. Desalination and Water Treatment, 8, 91-99. https://doi.org/10.5004/dwt.2009.668

[27] Ghernaout, D., Ghernaout, B. and Boucherit, A. (2008) Effect of pH on Electrocoagulation of Bentonite Suspensions in Batch Using Iron Electrodes. Journal of Dispersion Science and Technology, 29, 1272-1275. https://doi.org/10.1080/01932690701857483

[28] Ghernaout, D., Ghernaout, B., Saiba, A., Boucherit, A. and Kellil, A. (2009) Removal of Humic Acids by Continuous Electromagnetic Treatment Followed by Electrocoagulation in Batch Using Aluminium Electrodes. Desalination, 239, 295-308. https://doi.org/10.1016/j.desal.2008.04.001

[29] Saiba, A., Kourdali, S., Ghernaout, B. and Ghernaout, D. (2010) In Desalination, from 1987 to 2009, the Birth of a New Seawater Pretreatment Process: Electrocoagulation: An Overview. Desalination and Water Treatment, 16, 201-217. https://doi.org/10.5004/dwt.2010.1094

[30] Ghernaout, D. (2013) Advanced Oxidation Phenomena in Electrocoagulation Process: A Myth or a Reality? Desalination and Water Treatment, 51, 7536-7554. https://doi.org/10.1080/19443994.2013.792520

[31] Belhout, D., Ghernaout, D., Djezzar-Douakh, S. and Kellil, A. (2010) Electrocoagulation of a Raw Water of Ghrib Dam (Algeria) in Batch Using Iron Electrodes. Desalination and Water Treatment, 16, 1-9. https://doi.org/10.5004/dwt.2010.1081

[32] Ghernaout, D., Mariche, A., Ghernaout, B. and Kellil, A. (2010) Electromagnetic Treatment-Bi-Electrocoagulation of Humic Acid in Continuous Mode Using Response Surface Method for Its Optimization and Application on Two Surface Waters. Desalination and Water Treatment, 22, 311-329. https://doi.org/10.5004/dwt.2010.1120

[33] Ghernaout, D. and Naceur, M.W. (2011) Ferrate(VI): In Situ Generation and Water Treatment: A Review. Desalination and Water Treatment, 30, 319-332. https://doi.org/10.5004/dwt.2011.2217

[34] Ghernaout, D., Irki, S. and Boucherit, A. (2014) Removal of $\mathrm{Cu}^{2+}$ and $\mathrm{Cd}^{2+}$, and Humic Acid and Phenol by Electrocoagulation Using Iron Electrodes. Desalination and Water Treatment, 52, 3256-3270. https://doi.org/10.1080/19443994.2013.852484

[35] Irki, S., Ghernaout, D. and Naceur, M.W. (2017) Decolourization of Methyl Orange (MO) by Electrocoagulation (EC) Using Iron Electrodes under a Magnetic Field (MF). Desalination and Water Treatment, 79, 368-377. https://doi.org/10.5004/dwt.2017.20797

[36] Irki, S., Ghernaout, D., Naceur, M.W., Alghamdi, A. and Aichouni, M. (2018) Decolorization of Methyl Orange (MO) by Electrocoagulation (EC) Using Iron Electrodes under a Magnetic Field (MF). II. Effect of Connection Mode. World Journal 
of Applied Chemistry, 3, 56-64.

https://doi.org/10.11648/j.wjac.20180302.13

[37] Ghernaout, D. and Elboughdiri, N. (2019) Iron Electrocoagulation Process for Disinfecting Water: A Review. Applied Engineering, 3, 154-158.

[38] Ghernaout, D. and Elboughdiri, N. (2019) Mechanistic Insight into Disinfection Using Ferrate(VI). Open Access Library Journal, 6, e5946. https://doi.org/10.4236/oalib.1105946

[39] Ghernaout, D. and Elboughdiri, N. (2019) Water Disinfection: Ferrate(VI) as the Greenest Chemical: A Review. Applied Engineering, 3, 171-180.

[40] Ghernaout, D. and Ghernaout, B. (2010) From Chemical Disinfection to Electrodisinfection: The Obligatory Itinerary? Desalination and Water Treatment, 16, 156-175. https://doi.org/10.5004/dwt.2010.1085

[41] Ghernaout, D. and Ghernaout, B. (2011) On the Controversial Effect of Sodium Sulphate as Supporting Electrolyte on Electrocoagulation Process: A Review. Desalination and Water Treatment, 27, 243-254.

https://doi.org/10.5004/dwt.2011.1983

[42] Irki, S., Ghernaout, D., Naceur, M.W., Alghamdi, A. and Aichouni, M. (2018) Decolorizing Methyl Orange by Fe-Electrocoagulation Process: A Mechanistic Insight. International Journal of Environmental Chemistry, 2, 18-28.

https://doi.org/10.11648/j.ijec.20180201.14

[43] Ghernaout, D., Naceur, M.W. and Aouabed, A. (2011) On the Dependence of Chlorine by-Products Generated Species Formation of the Electrode Material and Applied Charge during Electrochemical Water Treatment. Desalination, 270, 9-22. https://doi.org/10.1016/j.desal.2011.01.010

[44] Ghernaout, D., Touahmia, M. and Aichouni, M. (2019) Disinfecting Water: Electrocoagulation as an Efficient Process. Applied Engineering, 3, 1-12.

[45] Ghernaout, D., Alghamdi, A. and Ghernaout, B. (2019) Electrocoagulation Process: A Mechanistic Review at the Dawn of Its Modeling. Journal of Environmental Science and Allied Research, 2, 51-67. https://doi.org/10.29199/2637-7063/ESAR-201019

[46] Ghernaout, D. and Elboughdiri, N. (2019) Electrocoagulation Process Intensification for Disinfecting Water: A Review. Applied Engineering, 3, 140-147.

[47] Ghernaout, D. (2019) Disinfection via Electrocoagulation Process: Implied Mechanisms and Future Tendencies. EC Microbiology, 15, 79-90.

[48] Holt, P.K. (2002) Electrocoagulation: Unraveling and Synthesizing the Mechanisms behind a Water Treatment Process. The University of Sydney, Sydney.

[49] Hakizimana, J.N., Gourich, B., Chafi, M., Stiriba, Y., Vial, C., Drogui, P. and Naja, J. (2017) Electrocoagulation Process in Water Treatment: A Review of Electrocoagulation Modeling Approaches. Desalination, 404, 1-21. https://doi.org/10.1016/j.desal.2016.10.011

[50] Kim, T.H., Park, C., Shin, E.B. and Kim, S. (2002) Decolorization of Disperse and Reactive Dyes by Continuous Electrocoagulation Process. Desalination, 150, 165-175. https://doi.org/10.1016/S0011-9164(02)00941-4

[51] Papadopoulos, K.P., Argyriou, R., Economou, C.N., Charalampous, N., Dailianis, S., Tatoulis, T.I., Tekerlekopoulou, A.G. and Vayenas, D.V. (2019) Treatment of Printing Ink Wastewater Using Electrocoagulation. Journal of Environmental Management, 237, 442-448. https://doi.org/10.1016/j.jenvman.2019.02.080

[52] Ben Hariz, I., Halleb, A., Adhoum, N. and Monser, L. (2013) Treatment of Petro- 
leum Refinery Sulfidic Spent Caustic Wastes by Electrocoagulation. Separation and Purification Technology, 107, 150-157. https://doi.org/10.1016/j.seppur.2013.01.051

[53] Mameri, N., Lounici, H., Belhocine, D., Grib, H., Piron, D.L. and Yahiat, Y. (2001) Defluoridation of Sahara Water by Small Plant Electrocoagulation Using Bipolar Aluminium Electrodes. Separation and Purification Technology, 24, 113-119. https://doi.org/10.1016/S1383-5866(00)00218-5

[54] Mameri, N., Yeddou, A.R., Lounici, H., Belhocine, D., Grib, H. and Bariou, B. (1998) Defluoridation of Septentrional Sahara Water of North Africa by Electrocoagulation Process Using Bipolar Aluminium Electrodes. Water Research, 32, 1604-1612. https://doi.org/10.1016/S0043-1354(97)00357-6

[55] Zhu, J., Zhao, H. and Ni, J. (2007) Fluoride Distribution in Electrocoagulation Defluoridation Process. Separation and Purification Technology, 56, 184-191.

https://doi.org/10.1016/j.seppur.2007.01.030

[56] Kobya, M., Demirbas, E. and Ulu, F. (2016) Evaluation of Operating Parameters with Respect to Charge Loading on the Removal Efficiency of Arsenic from Potable Water by Electrocoagulation. Journal of Environmental Chemical Engineering, 4, 1484-1494. https://doi.org/10.1016/j.jece.2016.02.016

[57] Dubrawski, K.L., Fauvel, M. and Mohseni, M. (2013) Metal Type and Natural Organic Matter Source for Direct Filtration Electrocoagulation of Drinking Water. Journal of Hazardous Materials, 244-245, 135-141. https://doi.org/10.1016/j.jhazmat.2012.11.027

[58] Dubrawski, K.L. and Mohseni, M. (2013) In-Situ Identification of Iron Electrocoagulation Speciation and Application for Natural Organic Matter (NOM) Removal. Water Research, 47, 5371-5380. https://doi.org/10.1016/j.watres.2013.06.021

[59] Vázquez, A., Nava, J.L., Cruz, R., Lázaro, I. and Rodríguez, I. (2014) The Importance of Current Distribution and Cell Hydrodynamic Analysis for the Design of Electrocoagulation Reactors. Journal of Chemical Technology \& Biotechnology, 89, 220-229. https://doi.org/10.1002/jctb.4105

[60] Vázquez, A., Rodríguez, I. and Lázaro, I. (2012) Primary Potential and Current Density Distribution Analysis: A First Approach for Designing Electrocoagulation Reactors. Chemical Engineering Journal, 179, 253-261. https://doi.org/10.1016/j.cej.2011.10.078

[61] Martinez-Delgadillo, S., Mollinedo-Ponce, H., Mendoza-Escamilla, V., Gutiérrez-Torres, C., Jiménez-Bernal, J. and Barrera-Diaz, C. (2012) Performance Evaluation of an Electrochemical Reactor Used to Reduce Cr(VI) from Aqueous Media Applying CFD Simulations. Journal of Cleaner Production, 34, 120-124. https://doi.org/10.1016/j.jclepro.2011.10.036

[62] Choudhary, A. and Mathur, S. (2017) Performance Evaluation of 3D Rotating Anode in Electro Coagulation Reactor: Part I: Effect of Impeller. The Journal of Water Process Engineering, 19, 322-330. https://doi.org/10.1016/j.jwpe.2017.08.020

[63] Gilhotra, V., Das, L., Sharma, A., Kang, T.S., Singh, P., Dhuria, R.S. and Bhatti, M.S. (2018) Electrocoagulation Technology for High Strength Arsenic Wastewater: Process Optimization and Mechanistic Study. Journal of Cleaner Production, 198, 693-703. https://doi.org/10.1016/j.jclepro.2018.07.023

[64] Song, P., Song, Q., Yang, Z., Zeng, G., Xu, X., Li, X. and Xiong, W. (2018) Numerical Simulation and Exploration of Electrocoagulation Process for Arsenic and Antimony Removal: Electric Field, Flow Field, and Mass Transfer Studies. Journal of Environmental Management, 228, 336-345. 
https://doi.org/10.1016/j.jenvman.2018.09.001

[65] Song, P., Yang, Z., Zeng, G., Yang, X., Xu, H., Wang, L., Xu, R., Xiong, W. and Ahmad, K. (2017) Electrocoagulation Treatment of Arsenic in Wastewaters: A Comprehensive Review. Chemical Engineering Journal, 317, 707-725.

https://doi.org/10.1016/j.cej.2017.02.086

[66] Villalobos-Lara, A.D., Pérez, T., Uribe, A.R., Alfaro-Ayala, J.A., de Jesús Ramírez-Minguela, J. and Minchaca-Mojica, J.I. (2020) CFD Simulation of Biphasic Flow, Mass Transport and Current Distribution in a Continuous Rotating Cylinder Electrode Reactor for Electrocoagulation Process. Journal of Electroanalytical Chemistry, 858, Article ID: 113807.

https://doi.org/10.1016/j.jelechem.2019.113807

[67] Castañeda, L.F., Coreño, O., Nava, J.L. and Carreño, G. (2020) Removal of Fluoride and Hydrated Silica from Underground Water by Electrocoagulation in a Flow Channel Reactor. Chemosphere, 244, Article ID: 125417.

https://doi.org/10.1016/j.chemosphere.2019.125417 